\title{
Bioconversion of AS1387392: bioconversion studies involving Amycolatopsis azurea JCM 3275
}

\author{
Satoshi Sasamura ${ }^{1}$, Keisuke Ohsumi ${ }^{2}$, Shigehiro Takase ${ }^{3}$, Toshiko Yamada ${ }^{1,8}$, Hideyuki Muramatsu ${ }^{4}$, \\ Akihiko Fujie ${ }^{5}$, Hiroaki Mori ${ }^{1,9}$, Takashi Fujii ${ }^{6,9}$, Motohiro Hino ${ }^{7}$, Kazutoshi Sakamoto ${ }^{4}$ and \\ Michizane Hashimoto ${ }^{4}$
}

We screened actinomycetes capable of converting AS1387392 to AS1429716 and identified those strains capable of hydroxylation. Amycolatopsis azurea JCM 3275 was found to be a particularly efficient strain, capable of converting AS1387392 to AS1429716, with a yield of $44 \%$ after $9 \mathrm{~h}$. This strain can metabolize not only the hydroxylation of phenylalanine at the meta and para positions but also the reduction of hydroxyketones, as shown by the isolation of bioconversion products. Examination of more suitable conversion conditions showed that $\mathrm{pH} 7.8$ and $25{ }^{\circ} \mathrm{C}$ were the optimum $\mathrm{pH}$ and temperature for bioconversion, respectively. We also demonstrated the effect of carbon and nitrogen sources in the culture media on hydroxylation. Using this strain, we were able to efficiently produce AS1429716 as a chemical template. Further derivatization studies may provide more effective, safer immunosuppressants than those that are currently on-market. The Journal of Antibiotics (2010) 63, 643-647; doi:10.1038/ja.2010.108; published online 6 October 2010

Keywords: Amycolatopsis azurea; AS1387392; AS1429716; bioconversion; histone deacetylase inhibitor; immunosuppressant

\section{INTRODUCTION}

The novel immunosuppressant AS1387392 (1) (Figure 1), isolated from Acremonium sp. No. 27082, has been found to exert a strong inhibitory effect against histone deacetylase (HDAC) with a good oral absorption profile. ${ }^{1}$ Although AS1429716 (2) (Figure 1) presents an attractive chemical template for synthesizing candidate immunosuppressant compounds subsequent to 1 , actually constructing, such a compound is difficult from a chemical stance.

Microorganisms are well known to be capable of hydoxylating various compounds. ${ }^{2-6}$ In our screening program, we identified 12 actinomycete strains capable of efficiently converting 1 to $2{ }^{7}$ We then focused our attention on Amycolatopsis azurea JCM 3275, a highly efficient strain. Here, we describe the isolation and biological activities of bioconversion products and investigate bioconversion conditions of A. azurea JCM 3275.

\section{MATERIALS AND METHODS}

\section{Media}

Medium A consisted of glucose $0.5 \%$, sucrose $0.5 \%$, oatmeal $0.5 \%$, yeast extract $0.2 \%$, peptone $0.5 \%$, peanut powder $0.5 \%$, humic acid $0.01 \%$, Tween $800.1 \%$ and $\mathrm{CaCO}_{3} 0.2 \%$, at $\mathrm{pH}$ 7.0. Medium B consisted of glycerol 6\%, soybean flour $1 \%$ and corn steep liquor 3\% (Nihon Shokuhin Kako, Tokyo, Japan), at $\mathrm{pH} 6.5$.

\section{Culture and bioconversion conditions}

The seed flask containing medium A was inoculated with a loopful of the A. azurea JCM 3275 plate culture. After incubation on a shaker at 250 r.p.m. for 3 days at $30^{\circ} \mathrm{C}$, the broth was transferred $(2 \%)$ into medium $\mathrm{B}$ and cultured for a further 2 days at 250 r.p.m. at $30^{\circ} \mathrm{C}$. Both growth stages contained $30 \mathrm{ml}$ of media in a 100-ml Erlenmeyer flask. After these cultivation periods, $14 \mathrm{ml}$ of culture broth and $6 \mathrm{ml}$ of solution containing $170 \mathrm{~mm}$ phosphate buffer (pH 6.5) and $1.7 \mathrm{mg} \mathrm{ml}^{-1}$ of compound 1 were transferred to a $100-\mathrm{ml}$ Erlenmeyer flask, and then the reaction mixtures were incubated on a shaker at 250 r.p.m. at $30{ }^{\circ} \mathrm{C}$ for $7 \mathrm{~h}$. Bioconversion stage contained $20 \mathrm{ml}$ of reaction mixtures in a 100-ml Erlenmeyer flask. Bioconversion ratio was expressed as the value of the products per initial substrate defined as high-performance liquid chromatography (HPLC) ratio.

\section{Sample analysis}

The reaction mixtures $(0.5 \mathrm{ml})$ were combined with an equal volume of acetone and centrifuged ( 3000 r.p.m., $10 \mathrm{~min}$ ), after which the supernatant was transferred to HPLC vials. Analysis was performed as previously described. ${ }^{7}$ Under these conditions, compound $\mathbf{1}$ and $\mathbf{2}$ were eluted at respective retention times of 9.8 and $4.6 \mathrm{~min}$.

Extraction and isolation of bioconversion products

The conversion reactions were incubated on a shaker for $7 \mathrm{~h}$. After reaction, the $200 \mathrm{ml}$ reaction mixtures from 10 flasks were extracted with an equal volume of acetone and filtered, and the filtrate was concentrated in vacuo and applied to a

${ }^{1}$ Pharmacology Research Laboratories, Astellas Pharma Inc., Tsukuba-shi, Ibaraki, Japan; ${ }^{2}$ Molecular Medicine Research Laboratories, Astellas Pharma Inc., Tsukuba-shi, Ibaraki, Japan; ${ }^{3}$ Analysis \& Pharmacokinetics Research Laboratories, Astellas Pharma Inc., Tsukuba-shi, Ibaraki, Japan; ${ }^{4}$ Fermentation Research Division, Astellas Research Technologies Co., Ltd., Tsukuba-shi, Ibaraki, Japan; ${ }^{5}$ Research Planning \& Administration, Astellas Pharma Inc., Tsukuba-shi, Ibaraki, Japan; ${ }^{6}$ Exploratory Research Laboratories, Astellas Pharma Inc., Tsukuba-shi, Ibaraki, Japan and 7 Fermentation and Biotechnology Laboratories, Astellas Pharma Inc., Kiyosu-shi, Aichi, Japan

8Current address: Astellas Research Institute of America, Skokie, IL, USA.

${ }^{9}$ Current address: Kikuchi Research Center, the Chemo-Sero-Therapeutic Research Institute, Kikuchi-shi, Kumamoto, Japan.

Correspondence: Dr S Sasamura, Pharmacology Research Laboratories, Astellas Pharma Inc., 21 Miyukigaoka, Tsukuba-shi, Ibaraki 305-8585, Japan.

E-mail: satoshi.sasamura@jp.astellas.com

Received 10 February 2010; revised 7 September 2010; accepted 9 September 2010; published online 6 October 2010 


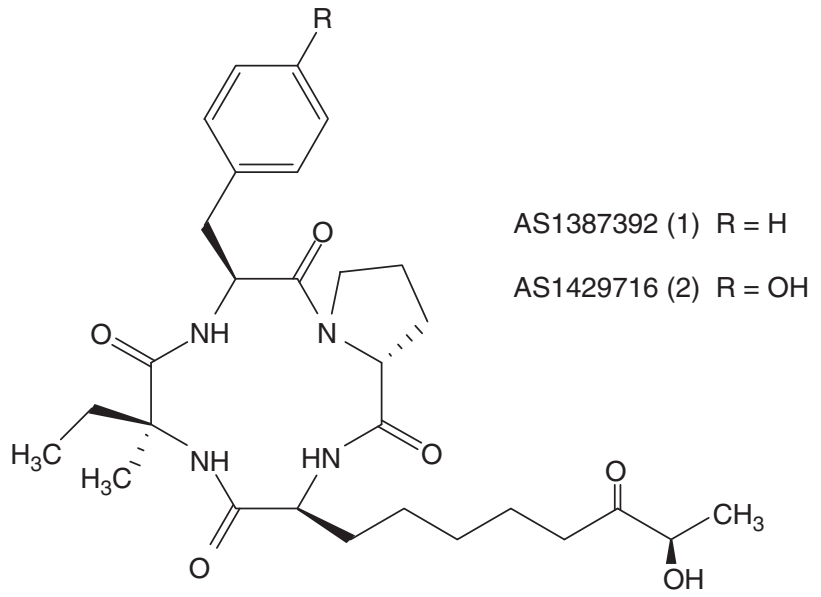

Figure 1 Structures of AS1387392 (1) and AS1429716 (2).

column of Diaion HP-20 (Mitsubishi Chemical, Tokyo, Japan). The column was eluted with both 30 and $40 \%$ aqueous acetonitrile.

All eluted fractions containing the bioconversion products were concentrated in vacuo to give an aqueous residue. This residue was extracted with ethyl acetate and the extracts were concentrated in vacuo to give an oily residue, which was subsequently dissolved in methanol. Compounds 2 to $\mathbf{6}$ were completely separated using preparative HPLC (column: Mightysil RP-18 GP $250 \mathrm{~mm} \times 20 \mathrm{~mm}$ I.D. (Kanto Chemical, Tokyo, Japan), flow rate: $10 \mathrm{ml} \mathrm{min}^{-1}$, mobile phase: $25-30 \%$ aqueous acetonitrile, detection: Ultraviolet absorption at $210 \mathrm{~nm}$ ). Each fraction containing bioconversion products was then concentrated in vacuo and dissolved in tert-butyl alcohol. Subsequent lyophilization produced $2(34.7 \mathrm{mg}), \mathbf{3}(7.7 \mathrm{mg}), \mathbf{4}(3.5 \mathrm{mg}), \mathbf{5}(16.2 \mathrm{mg})$ and $\mathbf{6}(4.3 \mathrm{mg})$ as a white powder.

\section{Compound 3}

${ }^{1} \mathrm{H}\left(500 \mathrm{MHz}, \mathrm{CDCl}_{3}\right) \delta 7.57(1 \mathrm{H}, \mathrm{d}, \mathrm{J}=10 \mathrm{~Hz}$, exchangeable), $7.14(1 \mathrm{H}, \mathrm{dd}$, $\mathrm{J}=8$ and $8 \mathrm{~Hz}), 7.09(1 \mathrm{H}, \mathrm{d}, \mathrm{J}=10 \mathrm{~Hz}$, exchangeable $), 6.78(1 \mathrm{H}, \mathrm{d}, \mathrm{J}=8 \mathrm{~Hz}), 6.71$ $(1 \mathrm{H}, \mathrm{s}), 6.68(1 \mathrm{H}, \mathrm{d}, \mathrm{J}=8 \mathrm{~Hz}), 5.88(1 \mathrm{H}, \mathrm{s}$, exchangeable $), 5.34(1 \mathrm{H}$, exchangeable), $5.18(1 \mathrm{H}, \mathrm{m}), 4.69(1 \mathrm{H}, \mathrm{br} \mathrm{d}, \mathrm{J}=8 \mathrm{~Hz}), 4.24(1 \mathrm{H}, \mathrm{m}), 4.21(1 \mathrm{H}, \mathrm{m}), 3.87$ $(1 \mathrm{H}, \mathrm{m}), 3.57(1 \mathrm{H}$, exchangeable), $3.32(1 \mathrm{H}, \mathrm{m}), 3.19(1 \mathrm{H}, \mathrm{dd}, \mathrm{J}=14$ and $9 \mathrm{~Hz})$, $2.92(1 \mathrm{H}, \mathrm{dd}, \mathrm{J}=14$ and $6 \mathrm{~Hz}), 2.50(1 \mathrm{H}, \mathrm{m}), 2.43(1 \mathrm{H}, \mathrm{m}), 2.35(2 \mathrm{H}, \mathrm{m}), 2.18$ $(2 \mathrm{H}, \mathrm{m}), 1.90-1.72(3 \mathrm{H}, \mathrm{m}), 1.60(3 \mathrm{H}, \mathrm{m}), 1.39(3 \mathrm{H}, \mathrm{d}, \mathrm{J}=7 \mathrm{~Hz}), 1.40-1.20$ $(4 \mathrm{H}, \mathrm{m}), 1.29(3 \mathrm{H}, \mathrm{s})$, and $0.84(3 \mathrm{H}, \mathrm{t}, \mathrm{J}=7.5 \mathrm{~Hz})$; HRESI-MS m/z 559.3126 $(\mathrm{M}+\mathrm{H})^{+}$, calculated: 558.30535 for $\mathrm{C}_{29} \mathrm{H}_{42} \mathrm{~N}_{4} \mathrm{O}_{7}$.

\section{Compound 4}

${ }^{1} \mathrm{H}\left(500 \mathrm{MHz}, \mathrm{CD}_{3} \mathrm{OD}\right) \delta$ 7.30-7.14 $(5 \mathrm{H}, \mathrm{m}), 5.12(1 \mathrm{H}, \mathrm{dd}, \mathrm{J}=8$ and $7 \mathrm{~Hz}), 4.78$ $(1 \mathrm{H}, \mathrm{br} \mathrm{d}, \mathrm{J}=8 \mathrm{~Hz}), 4.32(1 \mathrm{H}, \mathrm{t}, \mathrm{J}=7.5 \mathrm{~Hz}), 3.68(1 \mathrm{H}, \mathrm{m}), 3.55(1 \mathrm{H}, \mathrm{m}), 3.35$ $(1 \mathrm{H}, \mathrm{m}), 3.32(1 \mathrm{H}, \mathrm{m}), 3.15(1 \mathrm{H}, \mathrm{dd}, \mathrm{J}=14$ and $8 \mathrm{~Hz}), 2.94(1 \mathrm{H}, \mathrm{dd}, \mathrm{J}=14$ and $7 \mathrm{~Hz}), 2.28(2 \mathrm{H}, \mathrm{m}), 2.09(2 \mathrm{H}, \mathrm{m}), 1.84(1 \mathrm{H}, \mathrm{m}), 1.73(2 \mathrm{H}, \mathrm{m}), 1.57(3 \mathrm{H}, \mathrm{m})$, 1.44-1.22 $(6 \mathrm{H}, \mathrm{m}), 1.26(3 \mathrm{H}, \mathrm{s}), 1.14(3 \mathrm{H}, \mathrm{d}, \mathrm{J}=6.5 \mathrm{~Hz})$ and $0.79(3 \mathrm{H}, \mathrm{t}$, $\mathrm{J}=7.5 \mathrm{~Hz})$; HRESI-MS m/z $545.3342(\mathrm{M}+\mathrm{H})^{+}$, calculated 544.32609 for $\mathrm{C}_{29} \mathrm{H}_{44} \mathrm{~N}_{4} \mathrm{O}_{6}$.

\section{Compound 5}

${ }^{1} \mathrm{H}\left(500 \mathrm{MHz}, \mathrm{CDCl}_{3}\right) \delta 7.53(1 \mathrm{H}, \mathrm{d}, \mathrm{J}=10 \mathrm{~Hz}$, exchangeable), $7.10(2 \mathrm{H}, \mathrm{d}$, $\mathrm{J}=8 \mathrm{~Hz}), 7.09(1 \mathrm{H}, \mathrm{d}, \mathrm{J}=9 \mathrm{~Hz}$, exchangeable), $6.75(2 \mathrm{H}, \mathrm{d}, \mathrm{J}=8 \mathrm{~Hz}), 5.85(1 \mathrm{H}, \mathrm{s}$, exchangeable), $5.11(1 \mathrm{H}, \mathrm{m}), 4.83(1 \mathrm{H}$, exchangeable), $4.67(1 \mathrm{H}, \mathrm{br} \mathrm{d}, \mathrm{J}=8 \mathrm{~Hz})$, $4.20(1 \mathrm{H}, \mathrm{m}), 3.85(1 \mathrm{H}, \mathrm{m}), 3.78(1 \mathrm{H}, \mathrm{m}), 3.60(1 \mathrm{H}, \mathrm{m}), 3.27(1 \mathrm{H}, \mathrm{m}), 3.17$ $(1 \mathrm{H}, \mathrm{dd}, \mathrm{J}=14$ and $9 \mathrm{~Hz}), 2.88(1 \mathrm{H}, \mathrm{dd}, \mathrm{J}=14$ and $6 \mathrm{~Hz}), 2.33(2 \mathrm{H}, \mathrm{m}), 2.17$ $(2 \mathrm{H}, \mathrm{m}), 1.93-1.72(5 \mathrm{H}, \mathrm{m}), 1.65-1.50(3 \mathrm{H}, \mathrm{m}), 1.43-1.27(6 \mathrm{H}, \mathrm{m}), 1.28$ $(3 \mathrm{H}, \mathrm{s}), 1.15(3 \mathrm{H}, \mathrm{d}, \mathrm{J}=6.5 \mathrm{~Hz})$ and $0.83(3 \mathrm{H}, \mathrm{t}, \mathrm{J}=7.5 \mathrm{~Hz}) ; \mathrm{HRESI}-\mathrm{MS} \mathrm{m} / \mathrm{z}$ $561.3286(\mathrm{M}+\mathrm{H})^{+}$, calculated 560.32100 for $\mathrm{C}_{29} \mathrm{H}_{44} \mathrm{~N}_{4} \mathrm{O}_{7}$.

\section{Compound 6}

${ }^{1} \mathrm{H}\left(500 \mathrm{MHz}, \mathrm{CDCl}_{3}\right) \delta 7.56(1 \mathrm{H}, \mathrm{d}, \mathrm{J}=10 \mathrm{~Hz}$, exchangeable), $7.15(1 \mathrm{H}, \mathrm{dd}$, $\mathrm{J}=8$ and $8 \mathrm{~Hz}), 7.08(1 \mathrm{H}, \mathrm{d}, \mathrm{J}=10 \mathrm{~Hz}$, exchangeable), $6.80(1 \mathrm{H}, \mathrm{d}, \mathrm{J}=8 \mathrm{~Hz}), 6.71$ $(1 \mathrm{H}, \mathrm{s}), 6.69(1 \mathrm{H}, \mathrm{d}, \mathrm{J}=8 \mathrm{~Hz}), 5.88(1 \mathrm{H}, \mathrm{s}$, exchangeable $), 5.20(1 \mathrm{H}$, exchangeable), $5.18(1 \mathrm{H}, \mathrm{m}), 4.68(1 \mathrm{H}, \mathrm{br} \mathrm{d}, \mathrm{J}=8 \mathrm{~Hz}), 4.21(1 \mathrm{H}, \mathrm{m}), 3.85(1 \mathrm{H}, \mathrm{m}), 3.60$ $(1 \mathrm{H}, \mathrm{m}), 3.32(1 \mathrm{H}, \mathrm{m}), 3.30(1 \mathrm{H}, \mathrm{m}), 3.17(1 \mathrm{H}, \mathrm{dd}, \mathrm{J}=14$ and $9 \mathrm{~Hz}), 2.93(1 \mathrm{H}$, $\mathrm{dd}, \mathrm{J}=14$ and $6 \mathrm{~Hz}), 2.32(2 \mathrm{H}, \mathrm{m}), 2.22-2.10(4 \mathrm{H}, \mathrm{m}), 1.88-1.73(3 \mathrm{H}, \mathrm{m}), 1.65-$ $1.45(3 \mathrm{H}, \mathrm{m}), 1.44-1.27(6 \mathrm{H}, \mathrm{m}), 1.28(3 \mathrm{H}, \mathrm{s}), 1.20(3 \mathrm{H}, \mathrm{d}, \mathrm{J}=6.5 \mathrm{~Hz})$ and 0.83 $(3 \mathrm{H}, \mathrm{t}, \mathrm{J}=7.5 \mathrm{~Hz})$; HRESI-MS m/z $561.3286(\mathrm{M}+\mathrm{H})^{+}$, calculated 560.32100 for $\mathrm{C}_{29} \mathrm{H}_{44} \mathrm{~N}_{4} \mathrm{O}_{7}$.

\section{Assay for HDAC and splenocyte proliferation}

AS1387392 exerted potent inhibitory activity against HDAC and splenocyte proliferation stimulated by anti-CD3 antibody, which induced T-cell activation. Given this observed activity, the in vitro immunosuppressive activities of bioconversion products were examined by assaying HDAC and splenocyte proliferation by the method previously proposed by Mori et al. ${ }^{8}$ Briefly, $\mathrm{H}$ DAC and $\left[{ }^{3} \mathrm{H}\right]$-acetyl histones were prepared from human T-cell leukemia Jurkat cells. HDAC activity was determined on the basis of the release of $\left[{ }^{3} \mathrm{H}\right]$-acetic acid. Immunosuppressive activity was examined by assessing anti-CD3 antibody-stimulated splenocyte proliferation, induced when the antibody binds T-cell receptors and activates the proliferation response. Splenocytes harvested from female BALB/c mice (Charles River Japan, Kanagawa, Japan) were cultured in Roswell Park Memorial Institute (RPMI)1640 media containing $1 \mu \mathrm{g} \mathrm{ml}^{-1}$ anti-CD3 antibody at $37^{\circ}$ for 3 days in a $\mathrm{CO}_{2}$ incubator. After being cultured, proliferation was measured using alamar blue (Promega, Fitchburg, WI, USA).

\section{RESULTS}

Time-course of bioconversion products

Compound 2 was a major conversion product derived from $A$. azurea JCM 3275. After $9 \mathrm{~h}$, compound $\mathbf{1}$ had disappeared entirely and compound 2 had achieved its peak bioconversion ratio (44\%) after reaction initiation. HPLC analysis also revealed other bioconversion products (3-6), the time courses of which are shown in Figure 2. Levels of compound 4 increased rapidly and peaked at $3 \mathrm{~h}$, disappearing after $9 \mathrm{~h}$. Compound 3 achieved its peak conversion ratio at $9 \mathrm{~h}$, similar to 2, with the ratio gradually decreasing thereafter. In contrast, conversion ratios of compounds $\mathbf{5}$ and $\mathbf{6}$ increased as the reaction progressed.

\section{Isolation of bioconversion products}

The reaction mixtures were extracted with acetone and filtered, and concentrated extract was fractionated using a Diaion HP-20 (Mitsubishi Chemical) with 30 and $40 \%$ acetonitrile. The eluted fractions were concentrated in vacuo to give an aqueous residue and extracted with ethyl acetate. Compounds $\mathbf{2}$ to $\mathbf{6}$ were completely separated using preparative HPLC, yielding the bioconversion products 2 (34.7 mg), 3 (7.7 mg), 4 (3.5 mg), 5 (16.2 mg) and 6 (4.3 mg) as a white powder.

The physicochemical properties of the bioconversion products are described in Table 1. Ultraviolet absorption values were the same for compounds 1 and 4, whereas values for all other bioconversion products were approximately $280 \mathrm{~nm}$, a discriminative wavelength. The physicochemical properties of 2 were reported previously. $^{7}$

HRESI-MS data revealed the molecular formula of 3 to be $\mathrm{C}_{29} \mathrm{H}_{42} \mathrm{~N}_{4} \mathrm{O}_{7}$, the same as that of 2 . The ${ }^{1} \mathrm{H}$ nuclear magnetic resonance spectrum of $\mathbf{3}$ was quite similar to that of $\mathbf{2}$ except for the benzene moiety. The position of hydroxylation was determined to be meta on the basis of the three contiguous aromatic protons $(6.68,7.14$ and 6.78 p.p.m.) and one isolated (6.71 p.p.m.). The presence of a metatyrosine was further corroborated by long-range couplings of benzylic 
methylene protons (3.19 and 2.92 p.p.m.) to a singlet benzene proton (6.71 p.p.m.) and a doublet one (6.78 p.p.m.) in the ${ }^{1} \mathrm{H}-{ }^{1} \mathrm{H} \operatorname{COSY}\left({ }^{1} \mathrm{H}\right.$ nuclear magnetic resonance data; see the Materials and methods section).

HRESI-MS measurement of $\mathbf{4}$ afforded a molecular formula $\mathrm{C}_{29} \mathrm{H}_{44} \mathrm{~N}_{4} \mathrm{O}_{6}$ indicating the presence of two extra hydrogen atoms compared with 1 . Analysis of ${ }^{1} \mathrm{H}-{ }^{1} \mathrm{H}$ COSY data indicated the presence of $\mathrm{CH}_{3}-\mathrm{CH}(\mathrm{OH})-\mathrm{CH}(\mathrm{OH})-(1.14-3.55-3.35$ p.p.m.), indicating that Aoh (2-amino-8-oxo-9-hydroxydecanoic acid) in 1 was transformed into Add (2-amino-8,9-dihydroxydecanoic acid).

On the basis of ${ }^{1} \mathrm{H}$ nuclear magnetic resonance data analysis, transformation pattern of 5 was a combination of $\mathbf{2}$ and $\mathbf{4}$. Phe unit was oxidized to $\operatorname{Tyr}(\delta 7.10(2 \mathrm{H}, \mathrm{d}, \mathrm{J}=8 \mathrm{~Hz})$ and $6.75(2 \mathrm{H}, \mathrm{d}, \mathrm{J}=8 \mathrm{~Hz}))$ and Aoh unit was changed to Add.

HRESI-MS analysis of 6 afforded a molecular formula $\mathrm{C}_{29} \mathrm{H}_{44} \mathrm{~N}_{4} \mathrm{O}_{7}$, the same as that of 5. Analysis of ${ }^{1} \mathrm{H}^{-1} \mathrm{H}$ COSY data indicated the presence of a meta-tyrosine and Add $\left({ }^{1} \mathrm{H}\right.$ nuclear magnetic resonance data, see the Materials and methods section).

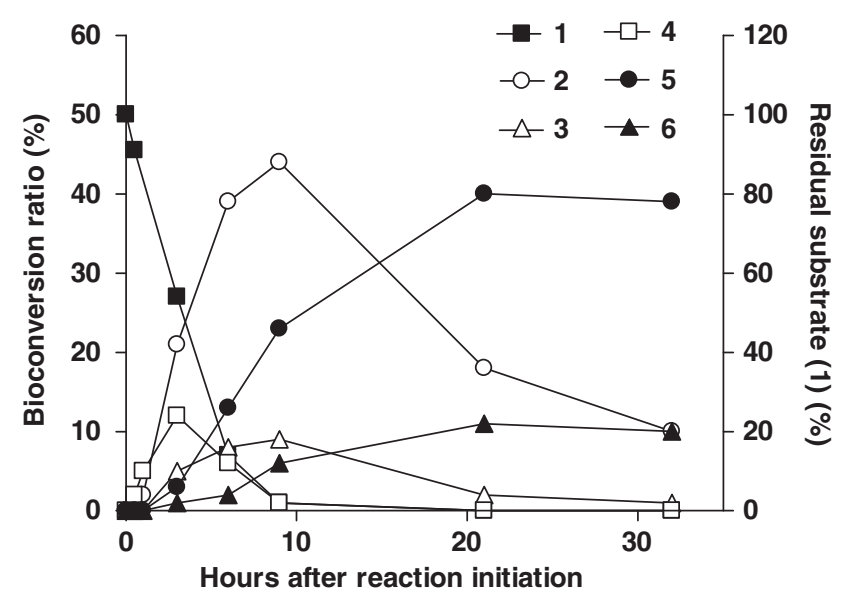

Figure 2 Time course of bioconversion products catalyzed by Amycolatopsis azurea JCM 3275. The bioconversion activity catalyzed by $A$. azurea JCM 3275 was assessed by high-performance liquid chromatography method. The $\mathrm{Y}$-axis on the left indicates the bioconversion ratios of compound 2-6, expressed as the value of the products per initial substrate. The $\mathrm{Y}$-axis on the right indicates the ratio of the residual substrate (compound $\mathbf{1}$ ).
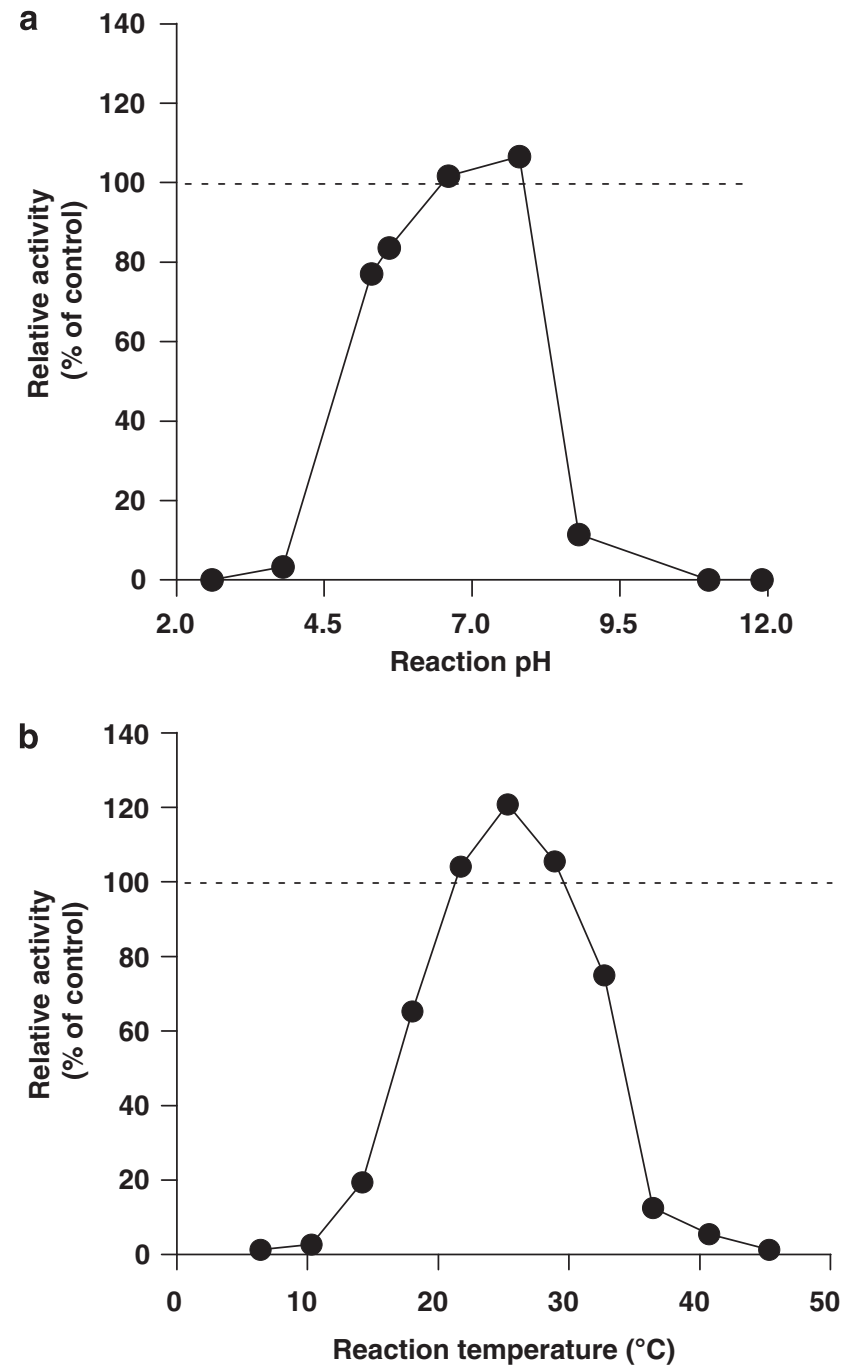

Figure 3 Effects of reaction $\mathrm{pH}$ (a) and temperature (b) on activity of the hydroxylation catalyzed by $A$. azurea JCM 3275 (dashed line indicates control activity at $30^{\circ} \mathrm{C}$ and $\mathrm{pH} 6.5$ ). The hydroxylation activity was estimated as the value of compound $\mathbf{2}$ per initial substrate in various conditions.

Table 1 Physicochemical properties of compounds 2-6

\begin{tabular}{|c|c|c|c|c|c|}
\hline & \multicolumn{5}{|c|}{ Value } \\
\hline & Compound $2^{\mathrm{a}}$ & Compound 3 & Compound 4 & Compound 5 & Compound 6 \\
\hline Appearance & white powder & white powder & white powder & white powder & white powder \\
\hline \multicolumn{6}{|l|}{$H R-E S I-M S(m / z)$} \\
\hline Found & $559.3122[\mathrm{M}+\mathrm{H}]^{+}$ & $559.3126[\mathrm{M}+\mathrm{H}]^{+}$ & $545.3342[\mathrm{M}+\mathrm{H}]^{+}$ & $561.3286[\mathrm{M}+\mathrm{H}]^{+}$ & $561.3286[\mathrm{M}+\mathrm{H}]^{+}$ \\
\hline Calculated & $559.3132[\mathrm{M}+\mathrm{H}]^{+}$ & $559.3126[\mathrm{M}+\mathrm{H}]^{+}$ & $545.3334[\mathrm{M}+\mathrm{H}]^{+}$ & $561.3283[\mathrm{M}+\mathrm{H}]^{+}$ & $561.3283[\mathrm{M}+\mathrm{H}]^{+}$ \\
\hline Molecular formula & $\mathrm{C}_{29} \mathrm{H}_{42} \mathrm{~N}_{4} \mathrm{O}_{7}$ & $\mathrm{C}_{29} \mathrm{H}_{42} \mathrm{~N}_{4} \mathrm{O}_{7}$ & $\mathrm{C}_{29} \mathrm{H}_{44} \mathrm{~N}_{4} \mathrm{O}_{6}$ & $\mathrm{C}_{29} \mathrm{H}_{44} \mathrm{~N}_{4} \mathrm{O}_{7}$ & $\mathrm{C}_{29} \mathrm{H}_{44} \mathrm{~N}_{4} \mathrm{O}_{7}$ \\
\hline UV $\lambda_{\max }(\mathrm{MeOH}) \mathrm{nm}(\log \varepsilon)$ & 223 (sh), 276 (3.75) & $276(3.15)$ & 237 (sh) & 224 (sh), 279 (3.40) & $275(3.26)$ \\
\hline HPLC retention time $(\min )^{\mathrm{b}}$ & 2.8 & 3.2 & 4.1 & 2.4 & 2.5 \\
\hline
\end{tabular}

Abbreviations: HPLC, high-performance liquid chromatography; HR-ESI-MS, high-resolution electrospray ionization mass spectrometry; UV, ultraviolet.

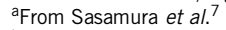

bHPLC condition: performed as the Materials and methods section except for the use of mightysil RP-18 GP $150 \mathrm{~mm} \times 4.6 \mathrm{~mm}$ as column and $40 \%$ aqueous acetonitrile as mobile phase. 


\section{Effect of $\mathrm{pH}$ and temperature on bioconversion}

Reaction conditions, such as $\mathrm{pH}$ and temperature, generally affect the rate of bioconversion. Investigation into reaction conditions most suitable for bioconversion showed that activity for converting $\mathbf{1}$ to 2 was highest at $\mathrm{pH} 7.8$ (Figure 3a). This activity was observed in a temperature range of approximately $15-35^{\circ} \mathrm{C}$ and proceeded most efficiently at $25^{\circ} \mathrm{C}$ (Figure $3 \mathrm{~b}$ ).

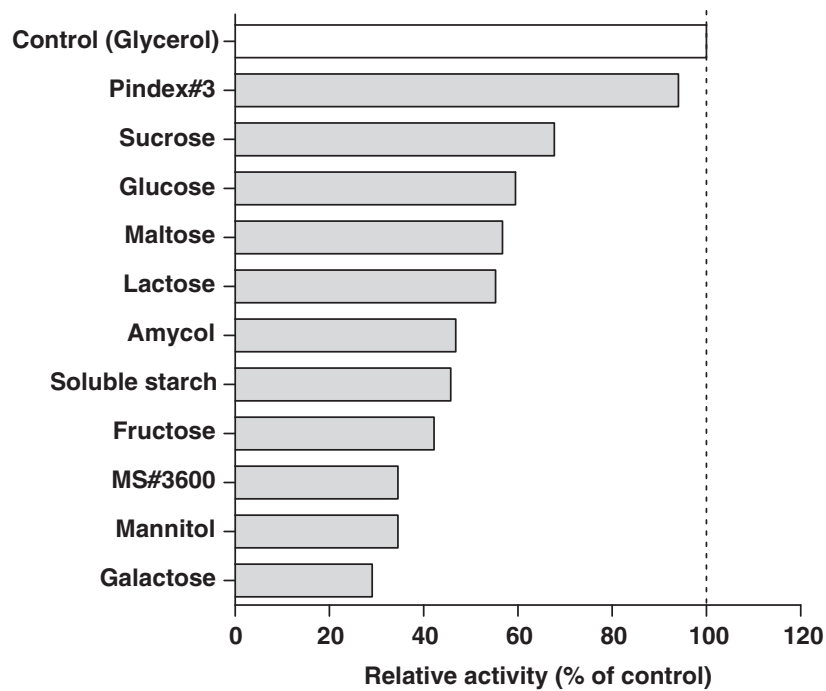

Figure 4 Effects of various carbon sources in culture media on hydroxylation activity catalyzed by $A$. azurea JCM 3275 (dashed line indicates control activity using $6 \%$ glycerol as carbon source). The hydroxylation activity was estimated as the value of compound $\mathbf{2}$ per initial substrate.

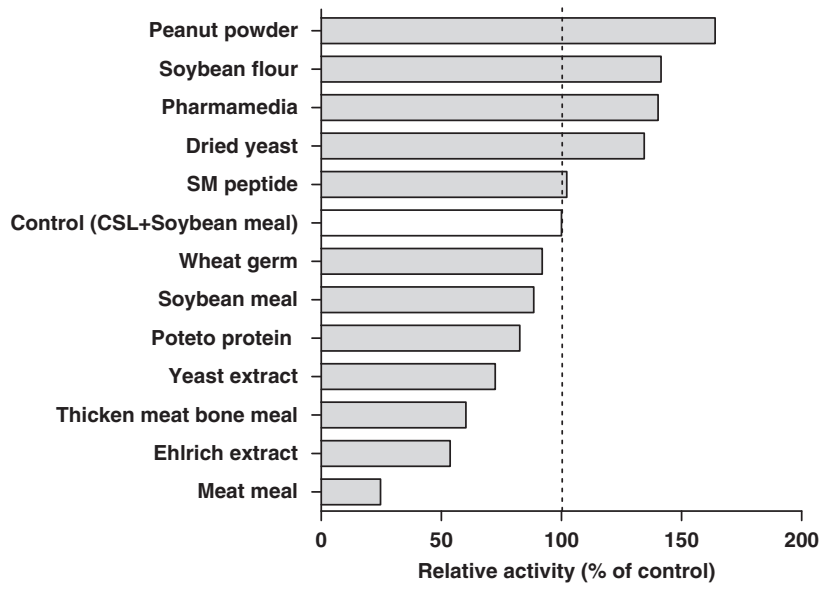

Figure 5 Effects of various nitrogen sources in culture media on hydroxylation activity catalyzed by $A$. azurea JCM 3275 (dashed line indicates control activity using $3 \%$ corn steep liquor (CSL) and $1 \%$ soybean meal as nitrogen source). The hydroxylation activity was estimated as the value of compound $\mathbf{2}$ per initial substrate.
Effect of carbon and nitrogen sources in the culture media on hydroxylation

To assess the optimum culture media for hydroxylation, the bioconversion activity was examined while culturing A. azurea JCM 3275 in media containing various carbon and nitrogen sources. Hydroxylation activity using media with Pindex\#3 was as efficient as that in control media (glycerol 6\%), whereas activity with other carbon sources was even lower (Figure 4). When corn steep liquor and soybean flour in medium B were exchanged for other nitrogen sources (2.5\%)—namely soybean flour, pharmamedia and dried yeast-hydroxylation activity increased in efficiency. The culture in media using peanut powder gave the highest activity (Figure 5).

Immunosuppressive activity of bioconversion products Compound $\mathbf{2}$ inhibited the activity of human partially purified HDAC $\left(\mathrm{IC}_{50}=12 \mathrm{ng} \mathrm{ml}^{-1}\right)$ and potently inhibited splenocyte proliferation $\left(\mathrm{IC}_{50}=1.2 \mathrm{ng} \mathrm{ml}^{-1}\right)$, demonstrating this compound to be as potent as $\mathbf{1}\left(\mathrm{IC}_{50}=1 \mathrm{ng} \mathrm{ml}^{-1}\right.$ in splenocyte proliferation and $\mathrm{IC}_{50}=18 \mathrm{ng} \mathrm{ml}^{-1}$ in HDAC assay). Compound 3 also inhibited splenocyte proliferation $\left(\mathrm{IC}_{50}=3.6 \mathrm{ng} \mathrm{ml}^{-1}\right)$. No obvious inhibitory effects were observed for compounds 4,5 or 6 at $1000 \mathrm{ng} \mathrm{ml}^{-1}$.

\section{DISCUSSION}

Here, we described our bioconversion study examining A. azurea JCM 3275. This strain was found to be able to convert 1 to 2 (44\% yield at $9 \mathrm{~h}$ ) and produce other bioconversion compounds (3-6) at the same time. We also drafted potential structures and metabolic pathways of the isolated compounds (Figure 6). These results suggest that A. azurea JCM 3275 is able to metabolize three positions on $\mathbf{1}$ : reduction of a hydroxyketone and hydroxylation of phenylalanine at the para and meta positions.

In our investigation of conditions more suitable for bioconversion than those known at present, the optimum $\mathrm{pH}$ and temperature for conversion were found to be $\mathrm{pH} 7.8$ and $25^{\circ} \mathrm{C}$, respectively. In addition, we determined optimum carbon and nitrogen sources in culture media for hydroxylation. These results will facilitate more effective production of 2 .

With regard to the time course, compound 2 achieved its maximum conversion ratio after $9 \mathrm{~h}$, with the ratio decreasing thereafter mainly because of the reduction of hydroxyketone (conversion to 5). Further improvement in conversion efficiency when using A. azurea JCM 3275 will require regulation of other bioconversion products. In particular, suppression of hydroxyketone reduction may improve the conversion yield, and the cloning and heterologous expression of the hydroxylation enzyme may help improve production of $2 .{ }^{9}$

The immunosuppressive activities of both 2 and 3 were as potent as 1. However, no activity was noted for 4,5 or $\mathbf{6}$, which were formed following reduction of a hydroxyketone, indicating that a hydroxyketone is essential for HDAC inhibition. Results of other studies have suggested that the epoxyketone group in trapoxin is necessary for HDAC inhibition. ${ }^{10}$ Our results, here, indicate that the hydroxyketone group may have the same role as epoxyketone.

In the present study, we were able to effectively produce AS1429716 as a chemical template by using the A. azurea strain JCM 3275. We obtained promising results in our study of natural product derivatization using bioconversion methods, suggesting that microbial transformations can indeed complement chemical modifications. Further derivatization studies may provide more effective and safer immunosuppressants than those that are currently available on-market. 


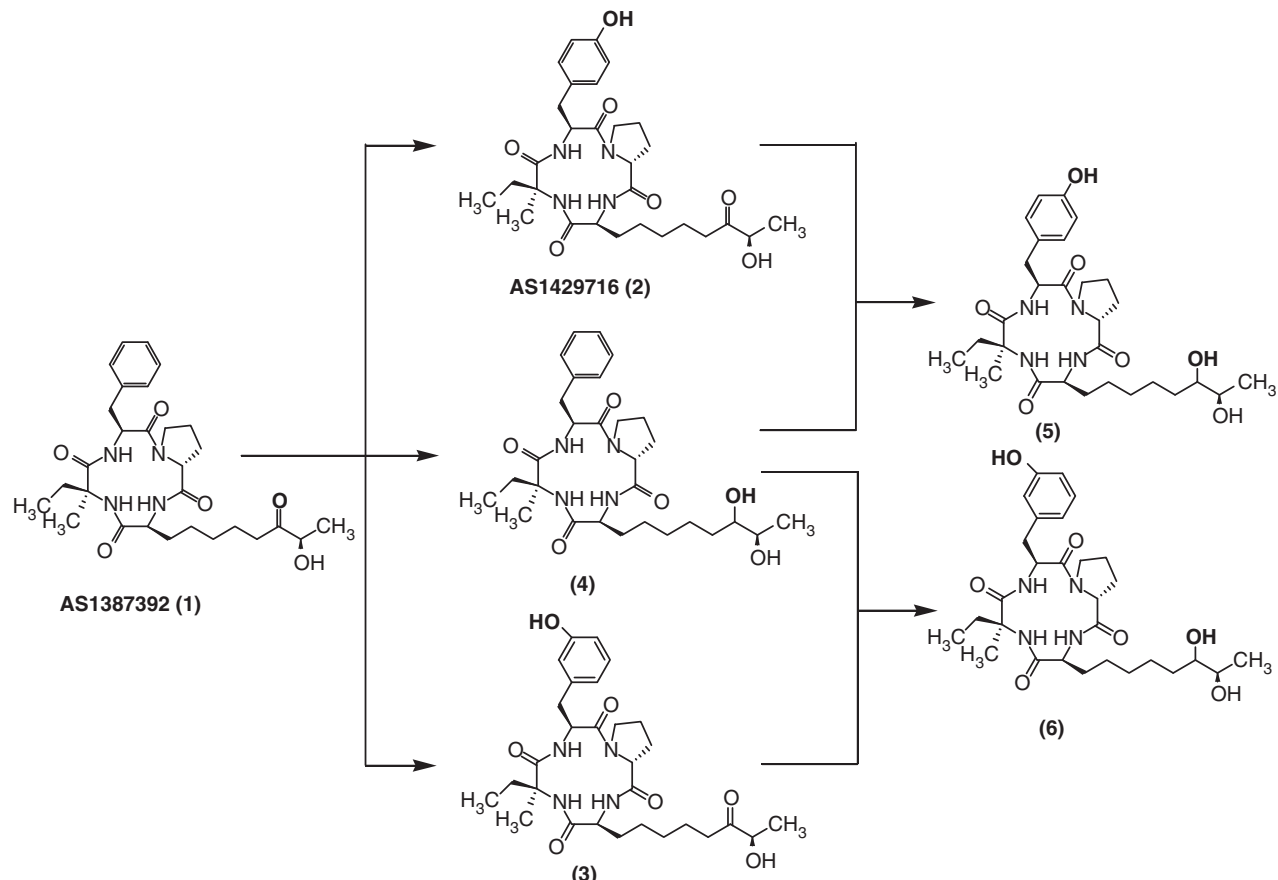

Figure 6 Proposed structures and metabolic pathways of bioconversion products.

\section{ACKNOWLEDGEMENTS}

The authors would like to thank Dr Yasuharu Urano for advice in the preparation of this paper.

1 Sasamura, S. et al. AS1387392, a novel immunosuppressive cyclic tetrapeptide compound with inhibitory activity against mammalian histone deacetylase. J. Antibiot. (e-pub ahead of print 30 June 2010; doi:10.1038/Ja.2010.51).

2 Serizawa, N., Serizawa, S., Furuya, K., Okazaki, T. \& Terahara, A. Microbial hydroxylation of ML-236B (compactin). Studies on microorganisms capable of 3 beta-hydroxylation of ML-236B. J. Antibiot. 36, 887-891 (1983).

3 Sasaki, J. et al. Transformation of vitamine $D_{3}$ to $1 \alpha$, 25-dihydroxyvitamine $D_{3}$ via 25-hydroxyvitamine $\mathrm{D}_{3}$ using Amycolata sp. strains. Appl. Microbiol. Biotechnol. 38, 152-157 (1992).

4 Schulman, M., Doherty, P., Zink, D. \& Arison, B. Microbial conversion of avermectins by Saccharopolyspora erthraea hydroxylation at C-27. J. Antibiot. 47, 372-375 (1994).
5 Nakagawa, K. \& Torikata, A. Microbial conversion of milbemycins: 30-oxidation of milbemycin A4 and related compounds by Amycolatata autotrophica and amycolatopsis mediterranei. J. Antibiot. 43, 1321-1328 (1990).

6 Hall, R. M. et al. The production of novel sordarin analogues by transformation. J. Antibiot. 54, 948-957 (2001).

7 Sasamura, S. et al. Bioconversion of AS1387392: screening and characterization of actinomycetes that convert AS1387392 to AS1429716. J. Antibiot. (e-pub ahead of print 28 July 2010; doi:10.1038/Ja.2010.89).

8 Mori, H. et al. FR235222, a fungal metabolite, is a novel immunosuppressant that inhibits mammalian histone deacetylase (HDAC). I. Taxonomy, fermentation, isolation and biological activities. J. Antibiot. 56, 72-79 (2003).

9 Ueno, M. et al. Cloning and heterologous expression of P450Um-1, a novel bacterial P450 gene, for hydroxylation of immunosuppressive agent AS1387392. J. Antibiot. (e-pub ahead of print 6 October 2010; doi:10.1038/Ja.2010.109).

10 Kijima, M., Yoshida, M., Sugita, K., Horinouchi, S. \& Beppu, T. Trapoxin, an antitumor cyclic tetrapeptide, is an irreversible inhibitor of mammalian histone deacetylase. J. Biol. Chem. 268, 22429-22435 (1993). 